\title{
Quality Evaluation and Antioxidant Activity of Inner Beauty Tea Prepared from
}

Roasted Lotus Root and Burdock

Yen-Hee Jung ${ }^{1}$, Jung-Soon $\operatorname{Han}^{2}$, Ae-Jung Kim ${ }^{1 *}$

${ }^{1}$ Department of Nutrition Therapy, Graduate School of Alternative Medicine, Kyonggi University, Seoul, Korea

${ }^{2}$ Research Institute of Human Ecology, College of Education, Korea University, Seoul, Korea

*Corresponding authors: Ae-Jung Kim, Department of Nutrition Therapy, Graduate School of Alternative Medicine Kyonggi University, 24, Kyonggidae-ro, 9-gil, Seodaemun-gu, Seoul 03746, Korea

Tel: + 8223905044

Fax: + 8223905078

Email:aj5249@naver.com

Running title: Quality Evaluation of Lotus Root and Burdock Tea

Ae-Jung Kim and Jung-Soon Han contributed equally to this work.

This work is part of the Yen-Hee Jung's M.S. thesis at the Kyonggi University, Seoul, Korea 


\begin{abstract}
Purpose: Twelve root vegetables are commonly domestically consumed in Korea. This study aimed to develop an inner beauty tea with the highest antioxidant activity prepared from the root vegetables. Methods: The antioxidant activities of these root vegetables and the corresponding teas prepared from them calculated by measuring the total polyphenol content and the radical scavenging activities of 1,1-diphenyl-2picrylhydrazyl (DPPH). The color, mechanical properties, textural characteristics, mineral content, and physiological activity of the teas were also measured. Results: The total polyphenol content of the 12 root vegetables was highest in burdock (72.09 mg tannic acid equivalent [TAE]/g) and lotus root (8.86 mg TAE/g). DPPH radical scavenging activity was also higher in burdock (90.21\%), and lotus root (87.83\%). The total polyphenol content and DPPH radical scavenging activity of roasted burdock (RB) extract tea was $99.86 \mathrm{mg} \mathrm{TAE} / \mathrm{g}$, and $89.11 \mu \mathrm{g} / \mathrm{mL}$, respectively, with the highest values obtained at $90^{\circ} \mathrm{C}$ extraction temperature. The $\mathrm{pH}$ (6.24) of roasted lotus root (RL) extract tea was the highest at $70^{\circ} \mathrm{C}$. The lightness (63.08) of RL root extract tea was the highest at $50{ }^{\circ} \mathrm{C}$. The redness (2.34) of RB extract tea was highest at $90^{\circ} \mathrm{C}$, while its yellowness $(31.03)$ was highest at $70^{\circ} \mathrm{C}$. These results suggest that roasting and leaching at high temperatures are efficient methods to increase antioxidant activity. Conclusion: The excellent antioxidant activities of lotus root and burdock make tem useful ingredients for inner beauty teas.
\end{abstract}

Keywords: Lotus root, Burdock, Roast, Inner beauty tea, Antioxidant activity 


\section{Introduction}

동양에서 차(茶)는 예로부터 단순한 음료에 대한 의미를 넘어서 정신문화와 함께 발전해왔다. 즉, 차 문화는 차를 중심으로 하는 생활문화와 소통문화를 규합한 전통문화라고 할 수 있다(Kim, 2014). 차는 사람의 기호식품으로 광합성에 의해 생성되는 자연합성물질인 식물의 열매나 줄기, 잎, 뿌리 등을 가공 처리함으로써 고유의 맛, 색, 향을 가진다(Lee et al., 2004). 한국 차의 소매시장 점유율은 옥수수 차 약 $24.7 \%$, 홍차 약 $14.2 \%$, 꿀 차 약 $7.6 \%$, 녹차 $5 \%$, 기타 $40 \%$ 로 뿌리채소를 이용한 차에 대한 생산 및 대중화는 현저히 적은 편이다(Ministry of Agriculture, Food and Rural Affairs, 2017). 이와 같이 차는 과일, 엽채류를 이용한 것들이 대부분이고 국내에서 많이 소비 되고 있는 뿌리채소를 이용한 차는 매우 드문 실정이다. 현대사회에서 차는 각종 스트레스에 노출되어 있는 현대인들에게 정신적 피로를 극복하고 여유를 회복하는데 도움을 줄 뿐 아니라 각종 항산화물질을 함유하고 있어 건강관리에도 긍정적이다(Jang et al., 2013). 이렇듯 우리가 일상생활에서 흔히 접하는 차는 최근 건강한 삶에 대한 요구 증가와 함께 손쉽게 마실 수 있는 음료 형태의 가공 식품이 개발되어 판매되고 있는 추세이다(Moon et al., 2010). 이러한 시대적 흐름에 맞추어 이너 뷰티 푸드(inner beauty food)는 기능성을 가진 식품을 통해 건강을 관리하는 식품으로 최근에 연구가 이루어지고 있다(Lee et al., 2018a, Lee et al., 2018b). 현대인들은 영양섭취 불균형, 수면부족, 운동부족 및 스트레스로 인하여 여러 가지 만성적인 질환에 시달리고 있으며(Kim \& Oh, 2008) 외부 환경오염 물질과 체내에서 대사과정 중에 발생하는 활성 산소는 생활습관병, 동맥경화, 암 등 다양한 질병의 원인이 된다(Kim et al., 2012). 또한 노화는 대사과정 중 발생하는 활성산소종인 수퍼옥사이드 이온(superoxide, $\mathrm{O}^{2-}$ ), 과산화수소(hydrogen peroxide, $\mathrm{H}_{2} \mathrm{O}_{2}$ ), 하이드록시 라디칼(hydroxyl radical, ·HO), 산화질소(nitric oxide, $\mathrm{NO}$ ), 이산화질소(nitrogen dioxide, $\mathrm{NO}_{2}$ ), 수산기(hydroxyl, $\mathrm{OH}^{-}$), 알콕시(alkoxy radical, $\mathrm{RO}$ ), 과수산기(hydroperoxyl radical, $\mathrm{HO}_{2}$ )등의 산화 반응에 기인하며, 이런 활성산소들은 체내 $\mathrm{DNA}$, 생체분자, 지질, 단백질, 그리고 핵산과 같은 물질의 손상을 유발한다(Fang et al., 2002). 그러므로 이러한 산화작용 및 질병들을 효율적으로 예방하기 위해선 항산화 물질의 섭취, 즉 항산화 기능을 가지고 있는 각종 채소나 과일 섭취가 필요하다(Lee et al., 2018c). 우엉(Burdock Arctium lappa L.)은 쌍떡잎식물 초롱꽃목 국화과에 속하는 식물로 재배되는 지역은 대부분 아시아 및 유럽의 
따뜻한 지역이고 우리나라에서는 주로 경상남도를 비롯하여 널리 재배되고 있다. 우엉의 뿌리는 우방근이라 하며 긴 방추상의 형태를 띠고, 길이 30-60 cm 윗부분의 지름은 2-4 $\mathrm{cm}$ 이고 바깥면은 흑갈색으로 주름 무늬가 있으며 속은 황백색을 띠고 있다(Tae et al., 2016). 우엉의 성분에 대한 연구로는 우엉 과실부위에서 분리된 리그난 성분의 arctigenin과 acrtiin의 효능이 보고되었으며(Jeong et al., 2011) arctigenin은 동물세포에서 열충격반응(heat shock response)의 억제 및 항암 효과가 보고되어 있다(Ishihara et al., 2006). 우엉의 생리활성에 중요한 성분으로는 chlorogenic acid, lignin 종류 중 하나인 arctigenin, 그리고 caffeoylquinic acid 등으로 밝혀졌다(Sugiura et al., 2009). 연근(Nelumbo nucifera)은 수련과에 속하는 여러해살이 초본식물로 원산지는 인도, 중국, 일본, 한국 및 시베리아 지역의 얕은 못이나 늪지에서 자라난다. 연근 잎은 높이가 1-1.5 m이고 뿌리가 옆으로 길게 뻗는다(Park et al., 2005). 연근에는 비타민 $\mathrm{A}, \mathrm{B}_{2}$ 및 니아신, 비타민 C, 캠퍼롤, 퀘르세틴 등과(Yang et al., 2007) 아미노산인 트리코네린, 알기닌, 티로신이 함유되어 있다(Kim et al., 2002). 참마는 전분이 주성분이지만 단백질과 무기질도 있으며 한방에서는 참마를 산약(Dioscorea radix)이라고 부르기도 하며 뿌리에는 아밀로스(amylose), 바타신(batasin), 뮤신(mucin), 점액(mucilage), 사포닌(saponin), 알라토인(allantoin) 등이 포함되어 있다(Huang et al., 2011). 참마 성분 중 하나인 아르기닌(arginine)은 혈관 내피세포에서 만들어지는 혈관 반응성 조절물질을 생성하는 비 필수아미노산이다(Kim et al., 2017). 또한 식물에서 항산화 물질로 잘 알려진 폴리페놀은 체내의 활성 산소를 자유라디칼로 안정시키어 산화 스트레스로 인한 손상을 예방하는 효과가 있다(Yoo et al., 2002).

이에 본 연구에서는 국내에서 많이 소비되고 있는 뿌리채소 12 종을 열수 추출한 후 total polyphenol 함량과 DPPH radical 소거능을 측정한 후 항산화 활성이 우수한 2종을 선정하여 로스팅하여 차를 제조한 후 혼합비율과 온도 변화에 따른 항산화능과 특성을 관찰하여 이너 뷰티 차로서의 가능성을 탐색하고자 하였다.

\section{Methods}

\section{1.실험 재료}

본 실험에 사용한 국내에서 많이 소비되고 있는 뿌리채소 12 종 우엉, 연근, 참마, 순무, 삼채, 당근, 마늘, 도라지, 감자, 토란, 양파, 더덕은 가락동 농수산물 시장(Seoul, 
Korea)에서 시판되는 것을 일괄 구매 하여 시료로 사용하였다.

\section{2. 추출물제조}

국내에서 많이 소비되고 있는 뿌리채소 12 종의 항산화활성 측정을 위해 시료 각각 100 $\mathrm{g}$ 무게 대비 10 배 부피의 증류수를 첨가한 후 환류냉각관을 부착한 $80^{\circ} \mathrm{C}$ 의 heating mantle (HM 250C; Sercrim LabTech, Korea)에서 2 h 추출시켜 여과(No.2, Whatman, England)하여 추출액을 얻었다.

\section{3. 차제조}

차 시료는 연근차 $180 \mathrm{~mL}(\mathrm{RL})$, 우엉차 $180 \mathrm{~mL}(\mathrm{RB})$, 연근차 $135 \mathrm{~mL}$ 와 우엉차 45 $\mathrm{mL}$ 를 혼합한 시료(RL3RB1), 연근차 $120 \mathrm{~mL}$ 와 우엉차 $60 \mathrm{~mL}$ 를 혼합한 시료(RL2RB1), 연근차 $90 \mathrm{~mL}$ 와 우엉차 $90 \mathrm{~mL}$ 를 혼합한 시료(RL1RB1), 연근차 $60 \mathrm{~mL}$ 와 우엉차 120 $\mathrm{mL}$ 를 혼합한 시료(RL1RB2), 연근차 $45 \mathrm{~mL}$ 와 우엉차 $135 \mathrm{~mL}$ 를 혼합한 시료(RL1RB3)(Park et al., 1994)의 방법을 참고하여 $50^{\circ} \mathrm{C}, 70^{\circ} \mathrm{C}, 90^{\circ} \mathrm{C}$ 의 물 $180 \mathrm{~mL}$ 에 연근과 우엉을 각각 $5 \mathrm{~g}$ 씩 넣어 $5 \mathrm{~min}$ 우려냈고, 그 다음에 우려낸 연근 차와 우엉 차는 Table 1 과 같이 7 종의 혼합차를 Figure 1 의 방법으로 제조하여 시료로 사용하였다.

\section{4. 색도 측정}

로스팅한 연근과 우엉을 이용하여 제조한 7종의 기능성 차의 색도는 색차계(Chroma Meter Cr-300; Minolta, Japan)를 사용하여 명도(lightness, L*), 적색도(redness, a*), 황색도(yellowness, b*)값으로 표시하였다. 각 시료 당 3회 반복 측정하여 그 평균값을 나타내었고 표준 백색판 $\left(\mathrm{L}^{*}=97.02, \mathrm{a}^{*}=1.32, \mathrm{~b}^{*}=+3.21\right)$ 을 사용하여 측정하였다.

\section{5. $\mathrm{pH}$ 측정}

로스팅한 연근과 우엉을 이용하여 제조한 7종의 기능성 차의 $\mathrm{pH}$ 값은 $\mathrm{pH}$ 측정기(Lab 870; Schott Instruments, Germany)를 이용하여 3회 반복 측정한 후 평균값으로 나타내었다.

\section{Total polyphenol 함량}

로스팅한 연근과 우엉을 이용하여 제조한 7 종의 기능성 차의 총 폴리페놀 함량은 Folin-Denis 의 방법(Folin \& Denis, 1912)을 변형한 방법에 따라 측정하였다. 1000 
$\mu \mathrm{g} / \mathrm{mL}$ 농도의 추출물 희석액 $1 \mathrm{~mL}$ 를 취하여 sodium carbonate $\left(\mathrm{Na}_{2} \mathrm{CO}_{3}\right.$; SigmaAldrich) 용액 $1 \mathrm{~mL}$ 를 가한 후 $3 \mathrm{~min}$ 정치한 후, $50 \%$ Folin-Ciocalteu 시약 (SigmaAldrich) $0.2 \mathrm{~mL}$ 를 가하여 반응시켜 microplate reader (BN 02514; Molecular Devices, $\mathrm{USA}$ )를 이용하여 $750 \mathrm{~nm}$ 에서 흡광도를 측정하였다. 총 폴리페놀 함량은 tannic acid (Sigma-Aldrich)를 이용하여 작성한 표준곡선을 바탕으로 tannic acid 로 환산하여 나타내었다.

\section{DPPH radical 소거능}

로스팅한 연근과 우엉을 이용하여 제조한 7종 차의 DPPH (Sigma-Aldrich, USA) 라디칼 소거능은 Blois의 방법(Blois, 1958)을 변형하여 다음과 같이 실시하였다. 시료 $0.1 \mathrm{~mL}$ 에 $1.5 \times 10^{-4} \mathrm{M} \mathrm{DPPH}$ 용액을 가하여 실온 암소에서 30 분간 정치한 후 microplate reader (BN 02514; Molecular Devices, USA)를 이용하여 $517 \mathrm{~nm}$ 에서 흡광도를 측정하였다. 모든 실험은 3 회 반복하여 평균값으로 계산하였다.

\section{8. 통계 처리}

본 연구에서 얻은 모든 자료는 3회 반복 측정한 값을 이용하여 mean士standard deviation로 나타내었고, 유의성 검증은 statistical package for social sciences (SPSS, ver. 24.0; SPSS Inc., USA)를 실시하였으며, 시료간의 유의성 차이는 Duncan's multiple range test로 $p<0.05$ 수준에서 검정을 실시하였다.

\section{Results and Discussion}

\section{1. 뿌리채소의 항산화능}

\section{1) Total polyphenol 함량}

국내산 다소비 뿌리채소 12 종의 total polyphenol 함량을 측정한 결과는 Table 2에 제시된 바와 같다. Total polyphenol 함량은 우엉 72.09 , 연근 58.86, 마늘 39.34, 토란 36.01, 도라지 31.01, 참마 26.70, 감자 26.46, 순무 26.25, 양파 23.48, 삼채 22.76, 더덕 14.44 , 당근 $8.36 \mathrm{mg} \mathrm{TAE} / \mathrm{g}$ 순으로 나타나 우엉과 연근이 다른 뿌리채소에 비해 total polyphenol 함량이 높게 나타났다.

\section{2) $\mathrm{DPPH}$ radical 소거능}


$\mathrm{DPPH}$ radical 소거능은 안정적인 자유라디칼로 함황 아미노산인 시스테인(cysteine), 글루타티온(glutathion), 방향족아민(aromatic amine), 아스코르브산(ascorbic acid)등에 의해 환원되어 보라색의 DPPH가 무색의 diphenyl-picrylhydrazine으로 탈색되면서 흡광도가 변하는 원리로 항산화능 측정에 유용한 방법으로(Cho et al., 2011) 국내산 다소비 뿌리채소 12 종 시료의 DPPH radical 소거능은 Table 3 에 제시된 바와 같다. 우엉 $90.21 \%$, 연근 $87.83 \%$, 순무 $86.81 \%$, 적양파 $75.24 \%$, 도라지 $74.17 \%$, 참마 $70.57 \%$, 감자 $69.73 \%$, 마늘 $61.93 \%$, 당근 $48.31 \%$, 더덕 $46.84 \%$, 토란 $33.68 \%$, 삼채 $31.78 \%$ 로 우엉, 연근, 순무 순으로 높게 나타났다. 이와 같은 결과는 Yamaguchi et al. (2001)이 우엉의 자유라디칼 소거능이 당근, 양파 등 18 가지 채소 중에서 우엉이 가장 높았다고 보고한 결과와 일치하였다.

\section{2. 로스팅한 연근과 우엉 차의 혼합비율과 온도 변화에 따른 항산화능}

1) Total polyphenol 함량

국내산 다소비 뿌리채소 12 종 가운데 항산화 활성이 우수한 연근과 우엉을 로스팅하여 차를 제조하고 이를 혼합하여 $50{ }^{\circ} \mathrm{C}, 70^{\circ} \mathrm{C}, 90^{\circ} \mathrm{C}$ 에서 우려낸 차의 total polyphenol 함량은 Table 4와 Table 5에 제시된 바와 같다. 연근만 로스팅하여 우려낸 차(RL)는 $50{ }^{\circ} \mathrm{C}$ 에서 $44.67,70{ }^{\circ} \mathrm{C}$ 에서 $45.10,90^{\circ} \mathrm{C}$ 에서 $45.37 \mathrm{mg} \mathrm{TAE} / \mathrm{g}$ 으로 $90^{\circ} \mathrm{C}$ 에서 우려내었을 때 함량이 가장 높게 나타났다. 우엉만 로스팅하여 우려낸 차 (RB)는 $50^{\circ} \mathrm{C}$ 에서 92.19 , $70{ }^{\circ} \mathrm{C}$ 에서 $98.11,90^{\circ} \mathrm{C}$ 에서 $99.86 \mathrm{mg} \mathrm{TAE} / \mathrm{g}$ 으로 $90^{\circ} \mathrm{C}$ 에서 우려내었을 때 함량이 가장 높게 나타났다. 연근을 로스팅하여 우려낸 차 $135 \mathrm{~mL}$ 과 우엉을 로스팅하여 우려낸 차 $45 \mathrm{~m}$ 를 혼합한 시료(RL3RB1)는 $50^{\circ} \mathrm{C}$ 에서 $63.77,70^{\circ} \mathrm{C}$ 에서 $75.23,90^{\circ} \mathrm{C}$ 에서 $82.77 \mathrm{mg}$ $\mathrm{TAE} / \mathrm{g}$ 을 나타내었으며, 연근을 로스팅하여 우려낸 차 $120 \mathrm{~mL}$ 과 우엉을 로스팅하여 우려낸 차 $60 \mathrm{~mL}$ 를 혼합한 차(RL2RB1)는 $50^{\circ} \mathrm{C}$ 에서 $68.95,70^{\circ} \mathrm{C}$ 에서 $82.41,90^{\circ} \mathrm{C}$ 에서 $91.44 \mathrm{mg} \mathrm{TAE} / \mathrm{g}$, 연근을 로스팅하여 우려낸 차 $90 \mathrm{~mL}$ 과 우엉을 로스팅하여 우려낸 차 $90 \mathrm{~mL}$ 를 혼합한 차(RL1RB1)는 $50^{\circ} \mathrm{C}$ 에서 $75.97,70{ }^{\circ} \mathrm{C}$ 에서 $91.23,90^{\circ} \mathrm{C}$ 에서 $96.85 \mathrm{mg}$ $\mathrm{TAE} / \mathrm{g}$, 연근을 로스팅하여 우려낸 차 $60 \mathrm{~mL}$ 과 우엉을 우려낸 차 $120 \mathrm{~mL}$ 를 혼합한 차 (RL1RB2)는 $50^{\circ} \mathrm{C}$ 에서 $81.61,70^{\circ} \mathrm{C}$ 에서 $95.32,90^{\circ} \mathrm{C}$ 에서 $98.02 \mathrm{mg} \mathrm{TAE} / \mathrm{g}$, 연근을 로스팅하여 우려낸 차 $45 \mathrm{~mL}$ 과 우엉을 로스팅하여 우려낸 차 $135 \mathrm{~mL}$ 를 혼합한 차(RL1RB3)는 $50{ }^{\circ} \mathrm{C}$ 에서 $84.27,70^{\circ} \mathrm{C}$ 에서 $95.34,90^{\circ} \mathrm{C}$ 에서 $99.75 \mathrm{mg} \mathrm{TAE} / \mathrm{g}$ 로 우려내는 
온도가 높아질수록, 우엉의 비율이 높아질수록 total polyphenol 함량은 높아졌다.

2) $\mathrm{DPPH}$ radical 소거능

$\mathrm{RL}$ 의 $\mathrm{DPPH}$ radical 소거능은 $50^{\circ} \mathrm{C}$ 에서 $79.66 \%, \quad 70^{\circ} \mathrm{C}$ 에서 $79.97 \%, \quad 90^{\circ} \mathrm{C}$ 에서 $82.93 \%$ 로 $90^{\circ} \mathrm{C}$ 에서 우려내었을 때 $\mathrm{DPPH}$ radical 소거능이 가장 높았다. $\mathrm{RB}$ 는 $50{ }^{\circ} \mathrm{C}$ 에서 $88.78 \%, 70^{\circ} \mathrm{C}$ 에서 $89.11 \%, 90^{\circ} \mathrm{C}$ 에서 $89.14 \%, \mathrm{RL} 3 \mathrm{RB} 1$ 는 $50^{\circ} \mathrm{C}$ 에서 $84.58 \%$, $70{ }^{\circ} \mathrm{C}$ 에서 $84.61 \%, 90^{\circ} \mathrm{C}$ 에서 $84.72 \%$ 로 $90^{\circ} \mathrm{C}$ 에서 우려내었을 때 DPPH radical 소거능이 가장 높았다. $\mathrm{RL} 2 \mathrm{RB} 1$ 는 $50^{\circ} \mathrm{C}$ 에서 $85.53 \%, 70^{\circ} \mathrm{C}$ 에서 $85.66 \%, 90^{\circ} \mathrm{C}$ 에서 $85.92 \%$, $\mathrm{RL} 1 \mathrm{RB} 1$ 는 $50^{\circ} \mathrm{C}$ 에서 $87.01 \%, \quad 70^{\circ} \mathrm{C}$ 에서 $87.08 \%, \quad 90^{\circ} \mathrm{C}$ 에서 $87.15 \%, \quad \mathrm{RL} 1 \mathrm{RB} 2$ 는 $50{ }^{\circ} \mathrm{C}$ 에서 $87.84 \%, 70^{\circ} \mathrm{C}$ 에서 $88.18 \%, 90^{\circ} \mathrm{C}$ 에서 $88.44 \%, \mathrm{RL} 1 \mathrm{RB} 3$ 는 $50^{\circ} \mathrm{C}$ 에서 $88.20 \%$, $70{ }^{\circ} \mathrm{C}$ 에서 $88.80 \%, \quad 90^{\circ} \mathrm{C}$ 에서 $88.86 \%$ 로 우려내는 온도가 높을수록, 우엉의 비율이 높아질수록 $\mathrm{DPPH}$ radical 소거능이 높아졌다. 이러한 결과는 로스팅은 페놀 화합물 추출을 용이하기 때문에 폴리페놀 함량이 높아진다고(Yun et al., 2012)한 연구와 폴리페놀은 고온의 열처리를 할 경우 용출이 더욱 증대된다고(Yoon et al., 2014)한 보고와 일치한다. 또한 Lee et al., (2013)이 결명자를 볶을 때 온도가 높아짐에 따라 폴리페놀 함량이 증가하였다는 결과와도 같은 경향을 나타내었다.

\section{2. 로스팅한 연근과 우엉 차의 혼합비율과 온도 변화에 따른 품질특성}

\section{1) $\mathrm{pH}$}

로스팅한 연근과 우엉 차의 혼합비율과 온도 변화에 따른 $\mathrm{pH}$ 는 Table 6에 제시한 바와 같다. $\mathrm{RL}$ 의 $\mathrm{pH}$ 는 $50^{\circ} \mathrm{C}$ 에서 $6.24,70^{\circ} \mathrm{C}$ 에서 $6.19,90^{\circ} \mathrm{C}$ 에서 6.15 로 우려내는 온도가 높아질수록 $\mathrm{pH}$ 가 낮아졌다. $\mathrm{RB}$ 의 $\mathrm{pH}$ 는 $50^{\circ} \mathrm{C}$ 에서 $5.83,70^{\circ} \mathrm{C}$ 에서 $5.86,90^{\circ} \mathrm{C}$ 에서 5.84 , RL3RB1의 $\mathrm{pH}$ 는 $50{ }^{\circ} \mathrm{C}$ 에서 $6.08,70^{\circ} \mathrm{C}$ 에서 $6.07,90^{\circ} \mathrm{C}$ 에서 6.00 , RL2RB1의 $\mathrm{pH}$ 는 $50{ }^{\circ} \mathrm{C}$ 에서 $6.00,70^{\circ} \mathrm{C}$ 에서 $6.04,90^{\circ} \mathrm{C}$ 에서 5.99 , RL1RB1의 $\mathrm{pH}$ 는 $50^{\circ} \mathrm{C}$ 에서 5.95 , $70{ }^{\circ} \mathrm{C}$ 에서 $5.98, \quad 90^{\circ} \mathrm{C}$ 에서 $5.91, \mathrm{RL} 1 \mathrm{RB} 2$ 의 $\mathrm{pH}$ 는 $50^{\circ} \mathrm{C}$ 에서 $5.94,70^{\circ} \mathrm{C}$ 에서 5.96 , $90^{\circ} \mathrm{C}$ 에서 $5.87, \mathrm{RL} 1 \mathrm{RB} 3$ 의 $\mathrm{pH}$ 는 $50^{\circ} \mathrm{C}$ 에서 $5.90,70^{\circ} \mathrm{C}$ 에서 $5.92,90^{\circ} \mathrm{C}$ 에서 5.85 로 우엉의 비율을 높였을 때 $\mathrm{pH}$ 는 다소 낮아졌지만 유의한 차이는 없었다. 


\section{2) 색도}

로스팅한 연근과 우엉 차의 혼합비율과 온도 변화에 따른 차의 색도는 Table 7, Table 8, Table 9와 Figure 1에 제시하였다. 명도(lightness, L*)값은 RL은 $50^{\circ} \mathrm{C}$ 에서 63.08 , $70{ }^{\circ} \mathrm{C}$ 에서 $59.05,90^{\circ} \mathrm{C}$ 에서 $54.03, \mathrm{RB}$ 는 $50^{\circ} \mathrm{C}$ 에서 $53.84,70^{\circ} \mathrm{C}$ 에서 $54.74,90^{\circ} \mathrm{C}$ 에서 50.95로 로스팅한 연근으로 우려낸 차보다 로스팅한 우엉으로 우려낸 차의 명도 값이 낮게 나타났으며, 우려내는 온도가 높아질수록 명도 값이 낮아졌다. RL3RB1는 $50^{\circ} \mathrm{C}$ 에서 $59.48,70^{\circ} \mathrm{C}$ 에서 $60.41,90^{\circ} \mathrm{C}$ 에서 $53.69, \mathrm{RL} 2 \mathrm{RB} 1$ 은 $50^{\circ} \mathrm{C}$ 에서 $59.29,70^{\circ} \mathrm{C}$ 에서 58.65 , $90^{\circ} \mathrm{C}$ 에서 $53.28, \quad \mathrm{RL} 1 \mathrm{RB} 1$ 은 $50^{\circ} \mathrm{C}$ 에서 $56.17, \quad 70^{\circ} \mathrm{C}$ 에서 $58.07, \quad 90^{\circ} \mathrm{C}$ 에서 53.02 , $\mathrm{RL} 1 \mathrm{RB} 2$ 는 $50^{\circ} \mathrm{C}$ 에서 $56.37,70^{\circ} \mathrm{C}$ 에서 $57.44,90^{\circ} \mathrm{C}$ 에서 $51.45, \mathrm{RL} 1 \mathrm{RB} 3$ 은 $50{ }^{\circ} \mathrm{C}$ 에서 $54.32,70^{\circ} \mathrm{C}$ 에서 $57.35,90^{\circ} \mathrm{C}$ 에서 50.50 으로 나타났다. 적색도(redness, a*)값은 RL은 $50{ }^{\circ} \mathrm{C}$ 에서 $-0.53,70^{\circ} \mathrm{C}$ 에서 $0.03,90^{\circ} \mathrm{C}$ 에서 $0.61, \mathrm{RB}$ 은 $50^{\circ} \mathrm{C}$ 에서 $1.28,70^{\circ} \mathrm{C}$ 에서 1.16 , $90^{\circ} \mathrm{C}$ 에서 2.34로 로스팅한 연근으로 우려낸 차보다 로스팅한 우엉으로 우려낸 차의 적색도가 높게 나타났고, 우려내는 온도가 높아질수록 적색도 값이 높아졌다. RL3RB1은 $50{ }^{\circ} \mathrm{C}$ 에서 $\quad-0.79, \quad 70^{\circ} \mathrm{C}$ 에서 $-0.82, \quad 90^{\circ} \mathrm{C}$ 에서 0.59 , RL2RB 1 은 $50^{\circ} \mathrm{C}$ 에서 -0.75 , $70{ }^{\circ} \mathrm{C}$ 에서 $-0.71,90^{\circ} \mathrm{C}$ 에서 $0.60, \mathrm{RL} 1 \mathrm{RB} 1$ 은 $50^{\circ} \mathrm{C}$ 에서 $-0.25,70^{\circ} \mathrm{C}$ 에서 $-0.65,90^{\circ} \mathrm{C}$ 에서 0.90, RL1RB2은 $50^{\circ} \mathrm{C}$ 에서 $-0.13,70^{\circ} \mathrm{C}$ 에서 $-0.58,90^{\circ} \mathrm{C}$ 에서 $1.40, \mathrm{RL} 1 \mathrm{RB} 3$ 은 $50^{\circ} \mathrm{C}$ 에서 0.50, $70^{\circ} \mathrm{C}$ 에서 $-0.48,90^{\circ} \mathrm{C}$ 에서 2.03 으로 나타났다. 황색도(yellowness, $b^{*}$ )값은 RL은 $50{ }^{\circ} \mathrm{C}$ 에서 $11.34,70^{\circ} \mathrm{C}$ 에서 $12.8290^{\circ} \mathrm{C}$ 에서 $14.70, \mathrm{RB}$ 는 $50^{\circ} \mathrm{C}$ 에서 $30.82,70^{\circ} \mathrm{C}$ 에서 31.03, $90^{\circ} \mathrm{C}$ 에서 31.01 로 로스팅한 연근으로 우려낸 차보다 로스팅한 우엉으로 우려낸 차의 황색도 값이 높게 나타났다. RL3RB1은 $50^{\circ} \mathrm{C}$ 에서 $15.23,70^{\circ} \mathrm{C}$ 에서 $15.12,90{ }^{\circ} \mathrm{C}$ 에서 20.87, RL2RB1은 $50^{\circ} \mathrm{C}$ 에서 $18.16,70^{\circ} \mathrm{C}$ 에서 $18.03,90^{\circ} \mathrm{C}$ 에서 $23.16, \mathrm{RL} 1 \mathrm{RB} 1$ 은 $50{ }^{\circ} \mathrm{C}$ 에서 $22.83, \quad 70^{\circ} \mathrm{C}$ 에서 $19.77, \quad 90^{\circ} \mathrm{C}$ 에서 $23.20, \quad \mathrm{RL} 1 \mathrm{RB} 2$ 은 $50^{\circ} \mathrm{C}$ 에서 24.23 , $70{ }^{\circ} \mathrm{C}$ 에서 $20.17, \quad 90^{\circ} \mathrm{C}$ 에서 $26.43, \mathrm{RL} 1 \mathrm{RB} 3$ 은 $50^{\circ} \mathrm{C}$ 에서 $25.79, \quad 70^{\circ} \mathrm{C}$ 에서 21.17 , $90^{\circ} \mathrm{C}$ 에서 28.40 으로 나타났다.

\section{Conclusion}

이상의 결과 뿌리채소 중 항산화 활성이 우수한 연근과 우엉을 로스팅하여 차를 제조한 후 혼합비율과 온도 변화에 따른 총 폴리페놀 함량과 DPPH radical 소거능은 로스팅한 우엉만을 $90^{\circ} \mathrm{C}$ 에서 우려낸 차 $\mathrm{RB}$ 가 가장 높게 나타났다. $\mathrm{pH}$ 는 로스팅한 연근만을 
$70^{\circ} \mathrm{C}$ 에서 우려낸 차 $\mathrm{RL}$ 이 가장 높게 나타났다. 명도는 로스팅한 우엉만을 $50^{\circ} \mathrm{C}$ 에서 우려낸 차 $\mathrm{RL}$ 이 가장 높게 나타났다. 적색도는 로스팅한 우엉만을 $90^{\circ} \mathrm{C}$ 에서 우려낸 차 $\mathrm{RB}$ 가 가장 높게 나타났다. 황색도는 로스팅한 우엉만을 $70^{\circ} \mathrm{C}$ 에서 우려낸 차 $\mathrm{RB}$ 가 가장 높게 나타났다. 즉, 우엉과 연근을 로스팅하여 $90^{\circ} \mathrm{C}$ 온도에서 우려낸 차가 폴리페놀 함량과 DPPH radical 소거능이 우수하여 항산화 차로서의 개발 가능성을 확인하였다. 향후 이러한 우엉과 연근 같은 뿌리채소를 이용한 피부건강에 도움이 되는 이너 뷰티 차(inner beauty tea) 개발에 대한 연구가 다양하게 이루어지기를 기대하는 바이다 


\section{References}

Blois MS. Antioxidant determinations by the use of a stable free radical. Nature, 181: 1199-1200, 1958.

Cho KJ, Cha JY, Yim JH, Kim JH. Effects of aging temperature and time on the conversion of garlic (Allium sativum L.) components. Journal of the Korean Society of Food Science and Nutrition, 40: 84-88, 2011.

Fang YZ, Yang S, Wu G. Free radicals, antioxidants, and nutrition. Nutrition, 10: 872879, 2002.

Folin O, Denis W. On phosphotungstic-phosphomolybdic compounds as color reagents. Journal of Biological Chemistry, 12: 239-243, 1912.

Huang ZL, Liang Z, Li GJ, Hong H. Response surface methodology to extraction of dioscorea polysaccharides and the effects on rat's bone quality. Carbohydrate Polymers, 83: 32-37, 2011.

Ishihara K, Yamagishi N, Saito Y, Takasaki M, Konoshima T, Hatayama T. Arctigenin from Fructus arctii is a novel suppressor of heat shock response in mammalian cells. Cell Stress \& Chaperones, 11: 154-161, 2016.

Jang CS, Yu GH. A study on the education program development of tea culture for the propagation of christianity. Journal of the Korean Tea Society, 19: 1-13, 2013.

Jeong JB, Hong SC, Jeong HJ, Koo JS. Arctigenin induces cell cycle arrest by blocking the phosphorylation of $\mathrm{Rb}$ via the modulation of cell cycle regulatory proteins in human gastric cancer cells. International Immunopharmacology, 11: 1573-1577, 2011.

Kim IS. Effect of Tea Culture Therapy Program on Object Relations for the Improvement of Interpersonal Relationship of Juvenile Probationers: Focused on Juvenile Probationers in 〈U-city>. The Journal of Korea Contents Association, 14: 199-210, 2014.

Kim JM, Shin YK, Kim BO, Kim JK, Lee SH, Kim YS. Effect of Artemisia capillaris extracts on antioxidant activity and allergic dermatitis. Korean Journal of Life Science, 22: 958-963, 2012.

Kim MS, Oh OH. An investigative analysis of recognition and uses for the codonopsis lanceolata in Seoul and Kyunggido area. Family and Environment Research, 46: 27-36, 2008.

Kim SA, Choi SC, Youn YH, Ko CI, Ha YS, Lee IA. Antioxidant and anti-inflammatory effects of Dioscorea japonica and Chenopodium album. Journal of the Society of Cosmetic Scientists of Korea, 43: 337-347, 2017. 
Kim YS, Jeon SS, Jung ST. Effect of lotus root powder on the baking quality of white bread. Korean Journal of Food and Cookery Science, 18: 413-425, 2002.

Lee GD, Yoon SR, Kim JO, Hur SS, Seo KI. Monitoring on the tea with steaming and drying process of germinated buckwheat. Journal of the Korean Society of Food Science and Nutrition, 33: 212-217, 2004.

Lee J, Chang MS, Kim GH. Quality characteristics and antioxidant activities of organically and conventionally grown carrot. Journal of the Korean Society of Dietary Culture, 30: 778-782, 2015.

Lee JY, Song H, Ko HC, Jang MG, Kim SJ. Anti-oxidant and anti-inflammatory potentials of Sasa quelpaertensis residue extracts. Journal of Life Sciences, 28: 738-744, 2018c.

Lee MH, Cho JH, Kim BK. Effect of roasting conditions on the antioxidant activities of Cassia tora L.. Korean Journal of Food Science and Technology, 45: 657-660, 2013.

Lee MS, Han JS, Kim AJ. Quality characteristics of inner beauty foods (Mook) prepared with mixture of mulberry leaf and fruit powder. Asian Journal of Beauty and Cosmetology, 16: 477- 486, $2018 \mathrm{a}$.

Lee SW, Choi HI, Han JS, Kim AJ. Applicability of sunsik with cultivated wild ginseng powder as a beauty food. Asian Journal of Beauty and Cosmetology, 16: 201210, 2018b.

Ministry of Agriculture, Food and Rural Affairs. 2017 Status of processed food segment market: tea market. At Korean Agro-Fisheries Trade Corporation, Jeollana-do, Nuju-si, 2017.

Moon JH, Sung JH, Choi IW, Kim YS. Anti-obesity and hypolipidemic activity of taro powder in mice fed with high fat and cholesterol diets. Korean Journal of Food Science and Technology, 42: 620-626, 2010.

Park SK, Kim JK, Kim JH, Moon KD, Oh SR. Study on the characteristic of physicochemical quality of oolong herbs tea by extraction conditions. Journal of the Korean Society of Dietary Culture, 9: 411-417, 1994.

Park SH, Hyun JS, Shin EH, Han JH. Functional evaluation of lotus root on serum lipid profile and health improvement. Journal of East Asian Society Dietary Life, 15: 257-263, 2005.

Sugiura Y, Torii T, Matsuda K, Yamada Y. Anti-allergic effects of extracts from commercial products of cooked burdock. Food Science Technology Research, 15: 
423-426, 2009.

Tae MH, Kim KH, Yook HS. Quality characteristics of castella with burdock (Arctium lappa L.) powder. Journal of the Korean Society of Food Science and Nutrition, 45: 215-221, 2016.

Yamaguchi T, Mizobuchi T, Kajikawa R, Kawashima H, Miyabe F, Terao J, Takamura $\mathrm{H}$, Matoba T. Radical-scavenging activity of vegetables and the effect of cooking on their activity. Food Science and Technology Research, 7: 250-257, 2001.

Yang HC, Heo NC, Choi KC, Ahn YJ. Nutritional composition of white-flowered and pink-flowered lotus in different parts. Korean Journal of Food Sciences and Technology, 39: 14-19, 2007.

Yoo SK, Kim MJ, Kim JW, Rhee SJ. Effects of YK-209 mulberry leaves on disaccharidase activities of small intestineland blood glucose-lowering in streptozotocin-induced diabetic rats. Journal of Korean Society of Food Science and Nutrition, 31: 1071-1077, 2002.

Yoon HS, Yu R, Noh JG, Kim YG, Kim SH, Choi SY, Han NS, Eom HJ. A comparative study on the physiological activities of puffed snack using miscellaneous cereals and grain crops. The Korean Journal of Food and Nutrition, 27: 962-970, 2014.

Yun UJ, Yang SY, Lee HS, Hong CO, Lee KW. Optimal roasting conditions for maximizing the quality of tea leached from high functional Perilla frutescens leaves. The Korean Journal of Food Science and Technology, 44: 34-40, 2012. 


\section{국문초록}

\section{로스팅한 연근과 우엉을 이용한 이너 뷰티 차의 항산화 활성과 품질 평가}

정연희 ${ }^{1}$, 한정순 ${ }^{2}$, 김애정 ${ }^{1 *}$

${ }^{1}$ 경기대학교 대체의학대학원 식품치료전공, 서울, 한국

${ }^{2}$ 고려대학교 생활과학연구소, 서울, 한국

목적: 본 연구는 국내에서 소비가 많이 되고 있는 뿌리채소 12 종 가운데 항산화 활성이 우수한 뿌리채소 2 종을 선정하여 로스팅한 후 차를 제조하여 혼합비율과 온도변화에 따른 품질평가를 하여 이너 뷰티 차를 개발하고자 수행되었다. 방법: 뿌리채소와 차의 총 폴리페놀 함량과 1,1-diphenyl-2-picrylhydrazyl (DPPH) radical 소거능 방법으로 항산화 활성을 측정하였다. 차의 품질 특성은 색도, 기계적 물성을 측정하였다. 결과: 뿌리채소 12 종의 총 폴리페놀 함량(total polyphenol content)을 측정한 결과 우엉(72.09 $\mathrm{mg} \mathrm{TAE} / \mathrm{g})$ 과 연근(8.86 mg TAE/g)이 높게 나타났다. $\mathrm{DPPH}$ radical 소거능도 우엉(90.21\%), 연근(87.83\%)이 높았다. 이에 우엉과 연근을 선정하여 로스팅한 후 우려낸 차의 총 폴리페놀 함량과 $\mathrm{DPPH}$ radical 소거능은 로스팅한 우엉만을 $90^{\circ} \mathrm{C}$ 에서 우려낸 차가 $99.86 \mathrm{mg} \mathrm{TAE} / \mathrm{g}, 89.11 \mathrm{\mu g} / \mathrm{mL}$ 로 항산화 활성이 가장 우수하였다. $\mathrm{pH}$ 는 로스팅한 연근만을 $70^{\circ} \mathrm{C}$ 에서 우려낸 차(RL)가 6.24 로 가장 높게 나타났다. 명도(L)는 로스팅한 연근만을 $50^{\circ} \mathrm{C}$ 에서 우려낸 차(RL)가 63.08로 가장 높게 나타났다. 적색도 (a)는 로스팅한 우엉만을 $90^{\circ} \mathrm{C}$ 에서 우려낸 차(RB)가 2.34로 가장 높게 나타났다. 황색도 (b)는 로스팅한 우엉만을 $70^{\circ} \mathrm{C}$ 에서 우려낸 차(RB)가 31.03 으로 가장 높게 나타났다. 이상의 결과 차 제조시 우엉을 로스팅하여 $90^{\circ} \mathrm{C}$ 에서 우려낸 것이 항산화 활성이 가장 높게 나타났다. 결론: 그러므로 뿌리채소인 로스팅한 우엉이나 연근을 이용한 차는 항산화 활성이 우수하여 이너 뷰티 차로 활용될 수 있을 것으로 사료된다.

핵심어: 연근, 우엉, 로스팅, 이너 뷰티 차, 항산화활성 


\section{참고문헌}

김명선, 오옥희. 서울, 경기지역의 더덕에 대한 인지도 및 이용실태 조사. Family and

Environment Research, 46: 27-36, 2008.

김신애, 최수철, 윤영한, 고창인, 하영순, 이인아. 참마와 명아주의 항산화 및 항염증

효과. 대한화장품학회지, 43: 337-348, 2017.

김영숙, 전순실, 정승태. 연근 분말 첨가가 제빵의 적성에 미치는 영향.

한국식품조리과학회지, 18: 413-425, 2002.

김인숙. 대인관계 향상을 위한 대상관계적 차문화치료 프로그램의 효과: 〈U시>의

보호관찰 청소년을 대상으로. 한국콘텐츠학회논문지, 14: 199-210, 2014.

김종명, 신용규, 김병오, 김종국, 이상한, 김윤섭. 인진호(Artemisia capillaris) 추출물의

항산화 활성 및 알러지성 피부염에 대한 효과. 생명과학회지 22: 958-963, 2012.

농림축산식품부. 2017 가공식품세분시장 현황: 음료류 시장. $\mathrm{aT}$ 한국농수산식품유통공사,

전란남도 나주시, 2017.

문지혜, 성지혜, 최인욱, 김윤숙. 고지방 식이를 섭취한 마우스에서 토란분말의 비만억제

및 지질저하 효과. 한국식품과학회지, 42: 620-626, 2010.

박상규, 김종국, 김준한, 문광덕, 오상룡. 추출조건에 따른 우롱차의 이화학적 품질특성에

관한 연구. 한국식생활문화학회지, 9: 411-417, 1994.

박성혜, 현중순, 신언환, 한종현. 고지방 식이에 있어 체내 지질농도 및 건강 개선에

미치는 연근 추출물의 기능성 평가. 동아시아식생활학회지, 15: 257-263, 2005.

양호철, 허남칠, 최경칠, 안양준. 백련(白蓮)과 홍련(紅蓮)의 부위별 영양성분.

한국식품과학회지, 39: 14-19, 2007.

유수경, 김미지, 김진원, 이순재. YK-209 뽕잎이 Streptozotocin 유발 당뇨쥐 소장의

이당류분해 효소 활성과 혈당강하에 미치는 영향. 한국식품영양과학회지, 31: 10711077, 2002.

윤향식, 유리, 노재관, 김이기, 김상희, 최송이, 한남수, 엄현주. 곡류 및 잡곡류를 이용한

팽화과자의 생리 활성 비교연구. 한국식품영양학회지, 27: 962-970, 2014.

윤웅재, 양성용, 이현순, 홍충의, 이광원. 고기능성 들깻잎을 이용한 침출차의 품질

극대화를 위한 최적 볶음조건 연구. 한국식품과학회지, 44: 34-40, 2012.

이기동, 윤성란, 김정옥, 허상선, 서권일. 메밀순의 증숙 및 건조에 다른 침출차 특성

모니터링. 한국식품영양과학회지, 33: 212-217, 2004.

이미선, 한정순, 김애정. 뽕입과 오디 혼합분말을 첨가한 이너 뷰티 푸드(묵) 제조 및

품질평가. 아시안뷰티화장품학술지, 16:477-486, 2018a.

이세우, 최형일, 김애정, 한정순. 산양삼 분말을 첨가한 선식의 미용기능성 식품으로서의 
응용가능성. 아시안뷰티화장품학술지, 16: 201-210, $2018 \mathrm{~b}$.

이주엽, 송하나, 고희철, 장미경, 김세재. 제주조릿대 잎 잔사 추출물의 항산화 및 항염 활성. 생명과학회지, 28: 738-744, 2018c.

이진, 장민선, 김건희. 유기 및 일반재배에 따른 당근의 품질비교. 한국식생활문화학회지 30: $778-782,2015$.

이명혜, 조진호, 김범근. 볶음 공정이 결명자의 항산화 활성에 미치는 영향. 한국식품과학회지, 45: 657-660, 2013.

장칠선, 유가효. 기독교 선교를 위한 차문화 교육프로그램 개발 연구. 한국차학회지, 19 : $1-13,2013$.

장혜림, 홍주연, 김남조, 김민하, 신승렬, 윤경영. 일반감자와 유색감자의 영양성분 및 이화학적 특성 비교. 원예과학기술지, 29: 144-150, 2011.

조강진, 차지영, 임주혁, 김재현. 온도 및 숙성기간이 마늘의 화학적 성분변화에 미치는 영향. 한국식품영양과학회지, 40: 84-88, 2011.

태미화, 김경희, 육흥선. 우엉분말을 첨가한 카스텔라의 품질 특성. 한국식품영양과학회지, 45: 215-221, 2016. 


\section{中文摘要}

\section{烤藕和牛蒡对内部美容茶的抗氧化活性和质量评价}

鄭姸姬 ${ }^{1}$, 韓正順 ${ }^{2}$, 金愛貞 ${ }^{1 *}$

1京畿大学代替医疗大学院, 食品治疗学科, 首尔, 韩国

2高丽大学生活科学研究所，首尔，韩国

目的: 在国内具有最多消费的 12 种根茎类蔬菜中, 选择具有高抗氧化活性的两种根类蔬菜来开 发内在美容茶。方法: 通过测定 1,1 -二茶基-2-苦基肼（DPPH）的总多酚含量和自由基清除活 性，测定这些根茎类蔬菜及其制备的相应茶叶的抗氧化活性。还测量了茶的颜色，机械性质， 质地特征, 矿物质含量和生理活性。结果: 牛蒡 ( $72.09 \mathrm{mg}$ 单宁酸当量 $[\mathrm{TAE}] / \mathrm{g}$ ) 和莲藕 ( $8.86 \mathrm{mg} \mathrm{TAE} / \mathrm{g})$ 中 12 种蔬菜的总多酚含量最高。牛蒡 $(90.21 \%)$ 和莲藕 $(87.83 \%)$ 的 $\mathrm{DPPH}$ 自由基清除活性也较高。烤牛蒡（RB）提取茶的总多酚含量和DPPH自由基清除活性分别为 $99.86 \mathrm{mg} \mathrm{TAE} / \mathrm{g}$ 和 $89.11 \mu \mathrm{g} / \mathrm{mL}$, 在 $90^{\circ} \mathrm{C}$ 提取温度下获得最高值。烤藕（RL）提取茶的 $\mathrm{pH}$ 值 (6. 24) 在 $70^{\circ} \mathrm{C}$ 时最高。 RL根提取物茶的轻度 (63.08) 在 $50^{\circ} \mathrm{C}$ 时最高。 RB提取茶的红度

(2.34) 在 $90^{\circ} \mathrm{C}$ 时最高, 而黄度 (31.03) 在 $70^{\circ} \mathrm{C}$ 时最高。这些结果表明, 在高温下焙烧和浸 出是增加抗氧化活性的有效方法。结论: 莲藕和牛蒡具有优异的抗氧化活性, 可用作内在美容 茶。

关键词: 莲藕, 牛蒡, 烤, 内在美茶, 抗氧化活性 
Table 1. Tea samples prepared from a mixture of roasted lotus (RL) root and burdock $(\mathrm{RB})$

(Unit: $\mathrm{mL}$ )

\begin{tabular}{lcc}
\hline \hline Groups & RL root & RB \\
RL & 180 & - \\
RB & - & 180 \\
RL3RB1 & 135 & 45 \\
RL2RB1 & 120 & 60 \\
RL1RB1 & 90 & 90 \\
RL1RB2 & 60 & 120 \\
RL1RB3 & 45 & 135 \\
\hline
\end{tabular}

RL, roasted lotus root; RB, roasted burdock; RL3RB1, ratio of 3 RL to 1 RB; RL2RB1, ratio of $2 \mathrm{RL}$ to $1 \mathrm{RB}$; RL1RB1, ratio of $1 \mathrm{RL}$ to $1 \mathrm{RB}$; RL1RB2, ratio of $1 \mathrm{RL}$ to $2 \mathrm{RB}$; RL1RB3, ratio of 1 RL to 3 RB. 
Table 2. Total polyphenol content of the extracts of 12 root vegetables commonly consumed in Korea

(Unit: mg TAE/g)

\begin{tabular}{lc}
\hline \hline Korean root vegetables & Total polyphenol \\
\hline Burdock (Arctium lappa) & $72.09 \pm 0.75^{2, \mathrm{a}, 3}$ \\
\hline Lotus root (Nelumbo nucifera Gaertn) & $58.86 \pm 0.58^{\mathrm{b}}$ \\
Deodeok (Codonopsis lanceolata) & $14.44 \pm 0.19^{\mathrm{h}}$ \\
Garlic (Allium scorodorpasumvvar.viviparum & $39.34 \pm 2.20^{\mathrm{c}}$ \\
Regel) & $8.36 \pm 0.02^{\mathrm{i}}$ \\
Carrot (Daucus carota var. sativa) & $23.48 \pm 0.34^{\mathrm{g}}$ \\
Onion (Allium cepa) & $26.70 \pm 0.90^{\mathrm{f}}$ \\
Yam (Colocasia esculenta) & $26.46 \pm 0.80^{\mathrm{f}}$ \\
Potato (Solanum tuberosum L.) & $36.01 \pm 0.68^{\mathrm{d}}$ \\
Tarp (C. esculenta) & $31.01 \pm 1.71^{\mathrm{e}}$ \\
Balloon flower (Platycodon grandiflorum) & $22.76 \pm 1.28^{\mathrm{g}}$ \\
Samche (Allium hookeri) & $26.25 \pm 0.53^{\mathrm{f}}$ \\
Turnip (Brassica rapa) & \\
\hline
\end{tabular}

TAE, tannic acid equivalent.

Mean \pm standard deviation $(n=3)$.

Different superscripts within a row $(a-i)$ indicate significant differences $(p<0.05)$. 
Table 3. The 1,1-diphenyl-2pecrylhydrazyl (DPPH) radical scavenging activities of the extracts of 12 root vegetables commonly consumed in Korea (\%)

\begin{tabular}{ll}
\hline \hline Korean root vegetables & DPPH radical \\
Burdock (Arctium lappa) & scavenging activity \\
Lotus root (Nelumbo nucifera Gaertn) & $90.21 \pm 0.91^{\mathrm{a}}$ \\
Deodeok (Codonopsis lanceolata) & $87.83 \pm 1.20^{\mathrm{a}}$ \\
Garlic (Allium scorodorpasumvvar.viviparum & $46.84 \pm 1.64^{\mathrm{d}}$ \\
Regel) & $61.93 \pm 2.43^{\mathrm{c}}$ \\
Carrot (Daucus carota var. sativa) & $48.31 \pm 1.46^{\mathrm{d}}$ \\
Onion (Allium cepa) & $75.24 \pm 8.79^{\mathrm{b}}$ \\
Yam (Colocasia esculenta) & $70.57 \pm 1.80^{\mathrm{b}}$ \\
Potato (Solanum tuberosum L.) & $69.73 \pm 0.54^{\mathrm{b}}$ \\
Tarp (C. esculenta) & $33.68 \pm 6.19^{\mathrm{e}}$ \\
Balloon flower (Platycodon grandiflorum) & $74.17 \pm 3.12^{\mathrm{b}}$ \\
\hline Samche (Allium hookeri) & $31.78 \pm 0.23^{\mathrm{e}}$ \\
\hline Meantstandard deviation (n=3); Different superscripts within a row (a-i) indicate & \\
\hline
\end{tabular}


Table 4. Total polyphenol contents of teas prepared by hot water extraction of RL root and $\mathrm{RB}$

\begin{tabular}{|c|c|c|c|c|c|}
\hline \multirow{2}{*}{ Groups } & \multirow{2}{*}{$\begin{array}{l}\mathrm{RL} \\
\text { root } \\
(\mathrm{mL})\end{array}$} & $\mathrm{RB}$ & \multicolumn{3}{|c|}{ Total polyphenol (mg TAE/mL) } \\
\hline & & $(\mathrm{mL})$ & $50^{\circ} \mathrm{C}^{3}$ & $70^{\circ} \mathrm{C}^{4}$ & $90^{\circ} \mathrm{C}^{5}$ \\
\hline RL & 180 & - & $44.67 \pm 0.27^{\mathrm{j}}$ & $45.10 \pm 0.27^{\mathrm{j}}$ & $45.37 \pm 0.36^{\mathrm{j}}$ \\
\hline $\mathrm{RB}$ & - & 180 & $92.19 \pm 0.57^{\mathrm{d}}$ & $98.11 \pm 1.21^{\mathrm{b}}$ & $99.86 \pm 1.87^{\mathrm{a}}$ \\
\hline RL3RB1 & 135 & 45 & $63.77 \pm 0.18^{\mathrm{i}}$ & $75.23 \pm 0.75^{\mathrm{g}}$ & $82.77 \pm 1.05^{\mathrm{f}}$ \\
\hline RL2RB1 & 120 & 60 & $68.95 \pm 0.10^{\mathrm{h}}$ & $82.41 \pm 0.38^{\mathrm{f}}$ & $91.44 \pm 0.97^{\mathrm{d}}$ \\
\hline RL1RB1 & 90 & 90 & $75.97 \pm 0.42^{\mathrm{g}}$ & $91.23 \pm 0.42^{\mathrm{d}}$ & $96.85 \pm 1.01^{\mathrm{b}}$ \\
\hline RL1RB2 & 60 & 120 & $81.61 \pm 0.24^{\mathrm{f}}$ & $95.32 \pm 0.68^{c}$ & $98.02 \pm 1.15^{\mathrm{b}}$ \\
\hline RL1RB3 & 45 & 135 & $84.27 \pm 0.26^{\mathrm{e}}$ & $95.34 \pm 0.16^{\mathrm{c}}$ & $99.75 \pm 0.52^{\mathrm{a}}$ \\
\hline
\end{tabular}

RL, roasted lotus root; RB, roasted burdock; RL3RB1, ratio of 3 RL to 1 RB; RL2RB1, ratio of $2 \mathrm{RL}$ to $1 \mathrm{RB}$; RL1RB1, ratio of $1 \mathrm{RL}$ to $1 \mathrm{RB}$; RL1RB2, ratio of $1 \mathrm{RL}$ to $2 \mathrm{RB}$; RL1RB3, ratio of 1 RL to 3 RB.

TAE, tannic acid equivalent.

Mean \pm standard deviation $(n=3)$; Different superscripts $(a-j)$ indicate significant differences $(p<0.05)$. 
Table 5. DPPH radical scavenging activities of tea samples prepared from a mixture of $\mathrm{RL}$ root and $\mathrm{RB}$

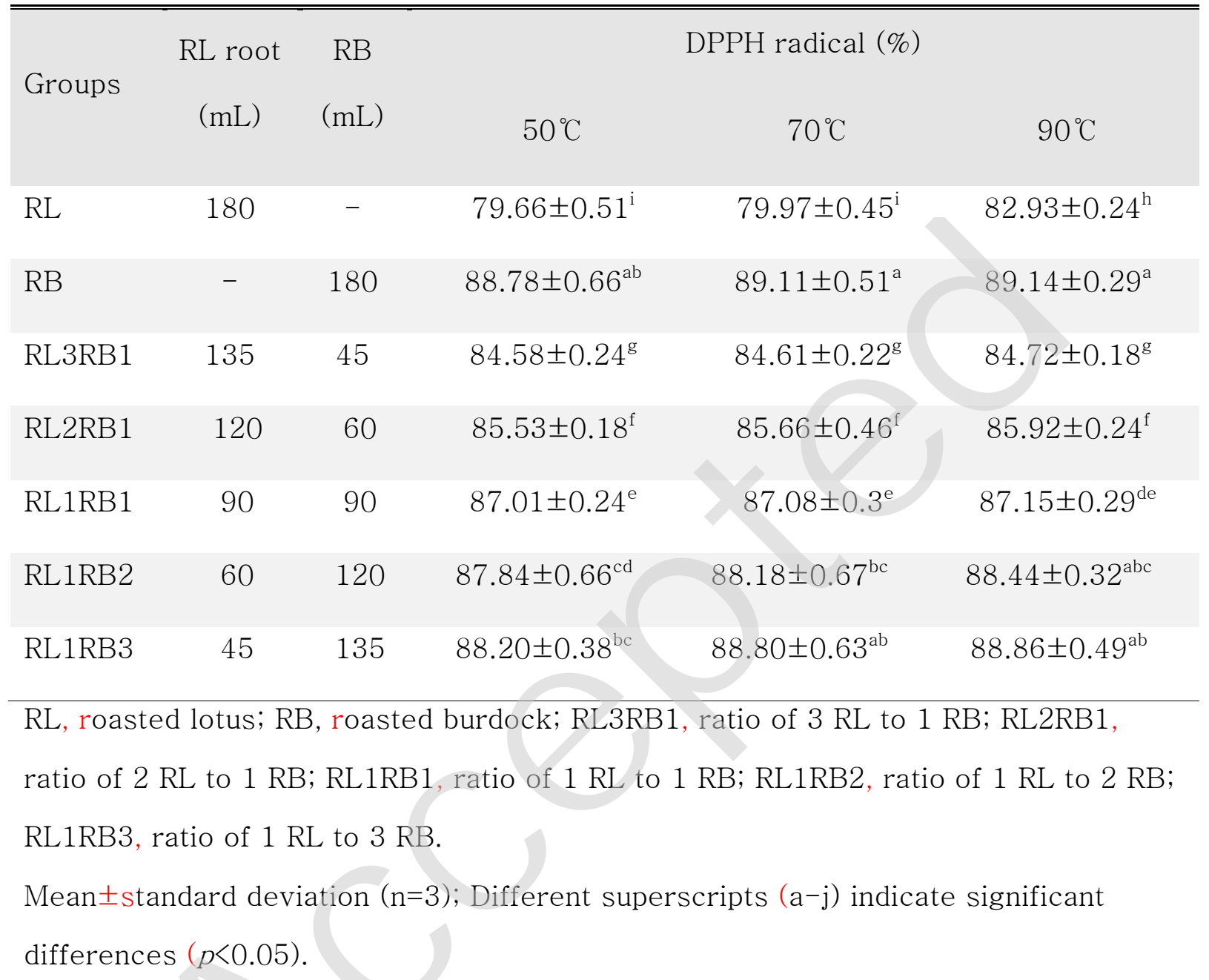


Table 6. The $\mathrm{pH}$ of tea samples prepared from a mixture of $\mathrm{RL}$ root and $\mathrm{RB}$

\begin{tabular}{|c|c|c|c|c|c|}
\hline \multirow{2}{*}{ Groups } & \multirow{2}{*}{$\begin{array}{l}\text { RL root } \\
(\mathrm{mL})\end{array}$} & \multirow{2}{*}{$\begin{array}{c}\mathrm{RB} \\
(\mathrm{mL})\end{array}$} & \multicolumn{3}{|c|}{$\mathrm{pH}$} \\
\hline & & & $50^{\circ} \mathrm{C}$ & $70^{\circ} \mathrm{C}$ & $90^{\circ} \mathrm{C}$ \\
\hline RL & 180 & & $6.24 \pm 0.01^{\mathrm{a}}$ & $6.19 \pm 0.01^{\mathrm{b}}$ & $6.15 \pm 0.01^{\mathrm{c}}$ \\
\hline $\mathrm{RB}$ & - & 180 & $5.83 \pm 0.01^{\circ}$ & $5.86 \pm 0.01^{1, \mathrm{~m}}$ & $5.84 \pm 0.01^{\mathrm{n}, \mathrm{o}}$ \\
\hline RL3RB1 & 135 & 45 & $6.08 \pm 0.01^{\mathrm{d}}$ & $6.07 \pm 0.01^{\mathrm{d}}$ & $6.00 \pm 0.01^{\mathrm{f}}$ \\
\hline RL2RB1 & 120 & 60 & $6.00 \pm 0.01^{\mathrm{f}}$ & $6.04 \pm 0.01^{\mathrm{e}}$ & $5.99 \pm 0.01^{\mathrm{f}, \mathrm{g}}$ \\
\hline RL1RB1 & 90 & 90 & $5.95 \pm 0.01^{\mathrm{h}, \mathrm{i}}$ & $5.98 \pm 0.01^{g}$ & $5.91 \pm 0.01^{\mathrm{jk}}$ \\
\hline RL1RB2 & 60 & 120 & $5.94 \pm 0.01^{\mathrm{i}}$ & $5.96 \pm 0.01^{\mathrm{h}}$ & $5.87 \pm 0.01^{1}$ \\
\hline RL1RB3 & 45 & 135 & $5.90 \pm 0.01^{\mathrm{k}}$ & $5.92 \pm 0.01^{\mathrm{j}}$ & $5.85 \pm 0.01^{\mathrm{m}, \mathrm{n}}$ \\
\hline \multicolumn{6}{|c|}{ RL, roasted lotus root; RB, roasted burdock; RL3RB1, ratio of 3 RL to 1 RB; RL2RB1 } \\
\hline \multicolumn{6}{|c|}{ ratio of 2 RL to $1 \mathrm{RB}$; RL1RB1, ratio of $1 \mathrm{RL}$ to $1 \mathrm{RB}$; RL1RB2, ratio of $1 \mathrm{RL}$ to $2 \mathrm{RB}$; } \\
\hline \multicolumn{6}{|c|}{ RL1RB3, ratio of $1 \mathrm{RL}$ to $3 \mathrm{RB}$. } \\
\hline Mean \pm st & ndard dev & tion $(\mathrm{n}$ & 3); Different s & perscripts $\left(a^{-}\right.$ & cate significant \\
\hline
\end{tabular}


Table 7. Color values of tea prepared from a mixture of $\mathrm{RL}$ root and $\mathrm{RB}$ at $50^{\circ} \mathrm{C}$

\begin{tabular}{lccc}
\hline \hline Groups & Lightness & Redness & Yellowness \\
\hline RL & $63.08 \pm 0.01^{\mathrm{a},}$ & $-0.53 \pm 0.00^{\mathrm{e}}$ & $11.34 \pm 0.01^{\mathrm{g}}$ \\
RB & $53.84 \pm 0.01^{\mathrm{g}}$ & $1.28 \pm 0.02^{\mathrm{a}}$ & $30.82 \pm 0.02^{\mathrm{a}}$ \\
RL3RB1 & $59.48 \pm 0.02^{\mathrm{b}}$ & $-0.79 \pm 0.01^{\mathrm{g}}$ & $15.23 \pm 0.01^{\mathrm{f}}$ \\
RL2RB1 & $59.29 \pm 0.01^{\mathrm{c}}$ & $-0.75 \pm 0.01^{\mathrm{f}}$ & $18.16 \pm 0.02^{\mathrm{e}}$ \\
RL1RB1 & $56.17 \pm 0.03^{\mathrm{e}}$ & $-0.25 \pm 0.01^{\mathrm{d}}$ & $22.83 \pm 0.02^{\mathrm{d}}$ \\
RL1RB2 & $56.37 \pm 0.07^{\mathrm{d}}$ & $-0.13 \pm 0.01^{\mathrm{c}}$ & $24.23 \pm 0.07^{\mathrm{c}}$ \\
RL1RB3 & $54.32 \pm 0.01^{\mathrm{f}}$ & $0.50 \pm 0.04^{\mathrm{b}}$ & $25.79 \pm 0.05^{\mathrm{b}}$ \\
\hline
\end{tabular}

RL, roasted lotus root; RB, roasted burdock; RL3RB1, ratio of 3 RL to 1 RB; RL2RB1, ratio of 2 RL to $1 \mathrm{RB}$; RL1RB1, ratio of $1 \mathrm{RL}$ to $1 \mathrm{RB}$; RL1RB2, ratio of $1 \mathrm{RL}$ to $2 \mathrm{RB}$; RL1RB3, ratio of 1 RL to $3 \mathrm{RB}$.

Mean \pm standard deviation $(n=3)$; Different superscripts $(a-j)$ indicate significant differences $(p<0.05)$. 
Table 8. Color values of tea prepared from a mixture of $\mathrm{RL}$ root and $\mathrm{RB}$ at $70^{\circ} \mathrm{C}$

\begin{tabular}{|c|c|c|c|}
\hline Groups & Lightness & Redness & Yellowness \\
\hline RL & $59.05 \pm 0.07^{b}$ & $0.03 \pm 0.03^{b}$ & $12.82 \pm 0.1^{g}$ \\
\hline $\mathrm{RB}$ & $54.74 \pm 0.01^{\mathrm{f}}$ & $1.16 \pm 0.01^{\mathrm{a}}$ & $31.03 \pm 0.05^{\mathrm{a}}$ \\
\hline RL3RB1 & $60.40 \pm 0.01^{\mathrm{a}}$ & $-0.82 \pm 0.00^{g}$ & $15.12 \pm 0.02^{\mathrm{f}}$ \\
\hline RL2RB1 & $58.65 \pm 0.02^{c}$ & $-0.71 \pm 0.01^{\mathrm{f}}$ & $18.03 \pm 0.01^{\mathrm{e}}$ \\
\hline RL1RB1 & $58.07 \pm 0.06^{\mathrm{d}}$ & $-0.65 \pm 0.01^{\mathrm{e}}$ & $19.77 \pm 0.04^{\mathrm{d}}$ \\
\hline RL1RB2 & $57.44 \pm 0.02^{\mathrm{e}}$ & $-0.58 \pm 0.01^{\mathrm{d}}$ & $20.11 \pm 0.06^{c}$ \\
\hline RL1RB3 & $57.38 \pm 0.14^{\mathrm{e}}$ & $-0.48 \pm 0.01^{\mathrm{c}}$ & $21.17 \pm 0.06^{\mathrm{b}}$ \\
\hline \multicolumn{4}{|c|}{$\begin{array}{l}\text { RL, roasted lotus root; RB, roasted burdock; RL3RB1, ratio of } 3 \text { RL to } 1 \text { RB; RL2 } \\
\text { ratio of } 2 \text { RL to } 1 \text { RB; RL1RB1, ratio of } 1 \text { RL to } 1 \text { RB; RL1RB2, ratio of } 1 \text { RL to } 2 \\
\text { RL1RB3, ratio of } 1 \text { RL to } 3 \mathrm{RB} \text {. } \\
\text { Mean } \pm \text { standard deviation }(n=3) \text {; Different superscripts }(a-j) \text { indicate significant }\end{array}$} \\
\hline
\end{tabular}


Table 9. Color values of tea prepared from a mixture of $\mathrm{RL}$ root and $\mathrm{RB}$ at $90^{\circ} \mathrm{C}$

\begin{tabular}{llll}
\hline \hline Groups & Lightness & Redness & Yellowness \\
\hline RL & $54.03 \pm 0.01^{\mathrm{a}}{ }^{\mathrm{a}}$ & $0.61 \pm 0.02^{\mathrm{e}}$ & $14.70 \pm 0.02^{\mathrm{f}}$ \\
RB & $50.95 \pm 0.02^{\mathrm{f}}$ & $2.34 \pm 0.03^{\mathrm{a}}$ & $31.01 \pm 0.02^{\mathrm{a}}$ \\
RL3RB1 & $53.69 \pm 0.03^{\mathrm{b}}$ & $0.59 \pm 0.03^{\mathrm{e}}$ & $20.87 \pm 0.02^{\mathrm{e}}$ \\
RL2RB1 & $53.28 \pm 0.01^{\mathrm{c}}$ & $0.60 \pm 0.04^{\mathrm{e}}$ & $23.16 \pm 0.02^{\mathrm{d}}$ \\
RL1RB1 & $53.02 \pm 0.04^{\mathrm{d}}$ & $0.90 \pm 0.04^{\mathrm{d}}$ & $23.20 \pm 0.05^{\mathrm{d}}$ \\
RL1RB2 & $51.45 \pm 0.02^{\mathrm{e}}$ & $1.40 \pm 0.08^{\mathrm{c}}$ & $26.43 \pm 0.13^{\mathrm{c}}$ \\
RL1RB3 & $50.50 \pm 0.03^{\mathrm{g}}$ & $2.03 \pm 0.07^{\mathrm{b}}$ & $28.40 \pm 0.19^{\mathrm{b}}$ \\
\hline
\end{tabular}

RL, roasted lotus root; RB, roasted burdock; RL3RB1, ratio of 3 RL to 1 RB; RL2RB1, ratio of 2 RL to $1 \mathrm{RB}$; RL1RB1, ratio of 1 RL to 1 RB; RL1RB2, ratio of 1 RL to 2 RB; RL1RB3, ratio of $1 \mathrm{RL}$ to $3 \mathrm{RB}$.

Mean \pm standard deviation $(n=3)$; Different superscripts $(a-j)$ indicate significant differences $(p<0.05)$. 
1st pan-frying of lotus root and burdock for $10 \mathrm{~min}$ at $70^{\circ} \mathrm{C}-100^{\circ} \mathrm{C}$

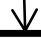

Rubbing of 1st pan-fried lotus root and burdock for 5 min $\downarrow$

2nd pan-frying of lotus root and burdock for $10 \mathrm{~min}$ at $70^{\circ} \mathrm{C}-100^{\circ} \mathrm{C}$

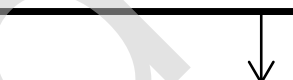

Rubbing of 2 nd pan-fried lotus root and burdock for 5 min

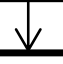

3rd pan-frying of lotus root and burdock for $10 \mathrm{~min}$ at $70^{\circ} \mathrm{C}-100^{\circ} \mathrm{C}$

Rubbing of 3rd pan-fried lotus root and burdock for 5 min

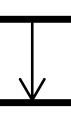

4th pan-frying of lotus root and burdock for $7 \mathrm{~min}$ at $40^{\circ} \mathrm{C}-70^{\circ} \mathrm{C}$

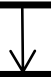

Rubbing of 4th pan-fried of lotus root and burdock for $3 \mathrm{~min}$

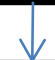

5th pan-frying of lotus root and burdock for $7 \mathrm{~min}$ at $40^{\circ} \mathrm{C}-70^{\circ} \mathrm{C}$

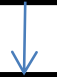

6th pan-frying of lotus root and burdock for $7 \mathrm{~min}$ at $40^{\circ} \mathrm{C}-70^{\circ} \mathrm{C}$

Figure 1. Protocol for roasting lotus root and burdock.

Drying of lotus root and burdock for $2 \mathrm{hr}$ at $30^{\circ} \mathrm{C} \sim 40^{\circ} \mathrm{C}$ 